\title{
BIOMASS AND NUTRIENT CYCLING IN PURE AND MIXED STANDS OF NATIVE TREE SPECIES IN SOUTHEASTERN BAHIA, BRAZIL ${ }^{(1)}$
}

\author{
Antonio Carlos da Gama-Rodrigues ${ }^{(2)}$, Nairam Félix de Barros ${ }^{(3)}$ \\ $\&$ Nicholas Brian Comerford ${ }^{(4)}$
}

\begin{abstract}
SUMMARY
The objective of this paper is to study selected components of the nutrient cycle of pure and mixed stands of native forest species of Atlantic Forest in southeastern Brazil. Tree diameter, height, above-ground biomass, and nutrient content were determined in 22-year-old stands. Litterfall, litter decomposition, and nutrient concentration were evaluated from August 1994 to July 1995. The following species were studied: Peltogyne angustiflora, Centrolobium robustum, Arapatiella psilophylla, Sclerolobium chrysophyllum, Cordia trichotoma, Macrolobium latifolium. The litter of a natural forest and a 40-year-old naturally regenerated second-growth forest was sampled as well. The mixed-species outmatched pure stands in height, stem volume and total biomass (29.4\% more). The greatest amount of forest litter was observed in the natural forest (9.3 $\left.\mathrm{Mg} \mathrm{ha}^{-1}\right)$, followed by the mixed-species stand (7.6 $\left.\mathrm{Mg} \mathrm{ha}^{-1}\right)$ and secondary forest $\left(7.3 \mathrm{Mg} \mathrm{ha}^{-1}\right)$, and least litterfall was measured in the pure C. robustum stand (5.5 $\left.\mathrm{Mg} \mathrm{ha}^{-1}\right)$. Litterfall seasonality varied among species in pure stands (CV from 44.7 to $91.4 \%$ ), unlike litterfall in the mixed-tree stand, where the variation was lower (CV $31.2 \%$ ). In the natural and second-growth forest, litterfall varied by 57.8 and $34.0 \%$, respectively. The annual rate of nutrient return via litterfall varied widely among forest ecosystems. Differences were detected between forest ecosystems in both the litter accumulation and quantity of litterlayer nutrients. The highest mean nutrient accumulation in above-ground biomass was observed in mixed-species stands. The total nutrient accumulation $(\mathrm{N}+\mathrm{P}+\mathrm{K}+\mathrm{Ca}+\mathrm{Mg})$ ranged from 0.97 to $1.93 \mathrm{~kg}$ tree ${ }^{-1}$ in pure stands, and from 1.21 to $2.63 \mathrm{~kg}_{\text {tree }}^{-1}$ in mixed-species stands.
\end{abstract}

\footnotetext{
(1) Recebido para publicação em maio de 2004 e aprovado em abril de 2007.

(2) Professor Associado do Laboratório de Solos, Centro de Ciências e Tecnologias Agropecuárias (CCTA), Universidade Estadual do Norte Fluminense Darcy Ribeiro - UENF. CEP 28013-602 Campos dos Goytacazes (RJ). Bolsista da FAPERJ. E-mail: tonygama@uenf.br

(3) Professor do Departamento de Solos, Universidade Federal de Viçosa - UFV. CEP 36570-000 Viçosa (MG). Bolsista do CNPq. E-mail: nfbarros@ufv.br

(4) Professor do Departamento de Ciência do Solo e da Água, Universidade da Flórida. 32611. Gainesville (FL). E-mail: nbc@mail.ifas.ufl.edu
} 
Soil fertility under mixed-species stands $(0-10 \mathrm{~cm})$ was intermediate between the primary forest and pure-stand systems. The litterfall rate of native forest species in a mixed-species system is more constant, resulting in a more continuous decomposition rate. Consequently, both nutrient availability and quantity of organic matter in the soil are higher and the production system ecologically more sustainable.

Index terms: Tropical forests, forest litter, soil fertility.

\title{
RESUMO: BIOMASSA E CICLAGEM DE NUTRIENTES POR ESPÉCIES FLORESTAIS NATIVAS EM PLANTIO PURO E MISTO NO SUDESTE DA BAHIA, BRASIL
}

\begin{abstract}
O objetivo deste trabalho foi avaliar alguns componentes da ciclagem de nutrientes em plantios puros e misto de espécies florestais nativas. O trabalho foi desenvolvido em solos de tabuleiro do sudeste da Bahia, Brasil, no período de agosto de 1994 a julho de 1995, em plantios com 22 anos de idade de pau-roxo (Peltogyne angustiflora), putumuju (Centrolobium robustum), arapati (Arapatiella psilophylla), arapaçu (Sclerolobium chrysophyllum), claraíba (Cordia trichotoma) e óleo-comumbá (Macrolobium latifolium). Como referências, foram utilizadas uma floresta secundária, praticamente em estado clímax, e uma capoeira de 40 anos de idade. O sistema de plantio misto proporcionou maior crescimento das espécies florestais em altura e volume de tronco e aumento médio de $29,4 \%$ de biomassa total. A maior produção de folhedo ocorreu na floresta natural (9,3 $\left.\mathrm{Mg} \mathrm{ha}^{-1}\right)$, seguida do plantio misto (7,6 Mg ha-1) e da capoeira (7,3 Mg ha-1). A menor produção de folhedo no plantio puro foi do putumuju $\left(5,5 \mathrm{Mg} \mathrm{ha}^{-1}\right)$. A sazonalidade da produção de folhedo variou entre as espécies nos plantios puros (CV 44,7 a 91,4\%), ao passo que o plantio misto apresentou menor variabilidade (CV 31,2\%). A variação na floresta natural foi de 57,8 \% e, na capoeira, de 34,0\%. A taxa de aporte anual de nutrientes via folhedo variou amplamente entre os ecossistemas florestais. Constataram-se, também, diferenças na acumulação e na quantidade de nutrientes da serapilheira entre os ecossistemas florestais. O plantio misto proporcionou, em média, os maiores acúmulos de nutrientes na biomassa da parte aérea. As espécies apresentaram amplitude na acumulação de nutrientes $(N+P+K+C a+M g)$ de 0,97 a $1,93 \mathrm{~kg}$ árvore ${ }^{-1}$ nos plantios puros e de 1,21 a 2,63 kg árvore-1 no plantio misto. A fertilidade do solo $(0-10 \mathrm{~cm})$ sob as espécies implantadas nos sistemas puro e misto diferiu marcadamente em relação à dos ecossistemas da capoeira e da floresta natural. O plantio de espécies florestais nativas em sistema misto resulta em taxa de produção de folhedo mais constante e, conseqüentemente, numa contínua decomposição deste. Assim, ele aumenta a disponibilidade de nutrientes e a quantidade de matéria orgânica no solo, o que pode ser caracterizado como um sistema de produção ecologicamente mais sustentável.
\end{abstract}

Termos de indexação: floresta tropical, folhedo, fertilidade do solo.

\section{INTRODUCTION}

Forest soils in humid tropical regions are usually highly weathered and characterized by an acidic $\mathrm{pH}$ with low inherent fertility. The climate allows a high rate of forest biomass production for which the nutrient demand is however high. Early in the life of a stand, the trees extract the full nutrient requirement from the soil. However, after reaching a certain stage in the forest development, part of these nutrients is supplied by the cycling process. Dynamics and magnitude of the contribution by nutrient redistribution vary among forest ecosystems. The microclimate and microorganism populations of forest soils are generally different from those associated with most agricultural soils. Litter production, decomposition, and fast nutrient cycling are dynamic processes that give soils under forest ecosystems a particular character.

The forest species of the Dense Ombrophylle Forest of the coastal tablelands in southeastern Bahia have varying capacities to absorb nutrients (Leão \& Silva, 1991) and to penetrate the naturally dense subsoil horizon, called coeso layer. In monoculture, these species cause alterations in soil physical and chemical 
properties (Silva, 1988), litterfall is season-dependent and litter decomposition rates are variable (Vinha \& Pereira, 1983; Vinha et al., 1985). The trees grow very slowly in height and diameter for the first 15 years after planting (Vinha \& Lobão, 1989).

Soil degradation is a serious problem in the coastal tablelands. Only about $8 \%$ of the area of native Atlantic Forest still remains (Corrêa, 1996). All the rest was deforested and is being used for other purposes, such as for extensively explored, low-quality pasture with increased erosion (Silva \& Mendonça, 2000), which possibly decreased the fertility of the already poor soils. A viable remediation strategy is the reforestation of degraded areas. A favorable nutrient cycle can reduce the loss of soil fertility and often invert the trend to soil degradation in a forest stand. Native as well as non-native tree species have been used for the reforestation of the Atlantic Forest in Brazil. Non-native species, such as eucalyptus, have been preferred in view of their commercial value.

An alternative to pure non-native or native-species stands in tropical regions is the use of mixed-species silviculture. The objective of this study was to compare selected components of the nutrient cycling process of native forest species growing in pure and mixed stands on the coastal tablelands of southeast Brazil.

\section{MATERIAL AND METHODS}

\section{Area}

This study was conducted at the Ecological Station Pau-Brasil (ESPAB), Porto Seguro, Bahia, Brazil $\left(16^{\circ} 23^{\prime} \mathrm{S}, 39^{\circ} 11^{\prime} \mathrm{W}\right)$. The natural vegetation is classified as Dense Ombrophylle Lowland Forest (Veloso et al., 1991), whose structural and physiognomic characteristics are similar to the Amazon Rain Forest (Mori \& Silva, 1980). According to the Köppen system, the climate is classified as AF (even rainfall distribution throughout the year, no well-defined dry season). The soil is a Paleudult, clayey, oxidic, isohyperthermic, deep ( $>2 \mathrm{~m})$, very acid, with very low natural fertility (Leão \& Melo, 1990; Silva, 1991). The area had formerly been used for low-input agriculture and as pasture, with annual burning, and then left fallow for over five years before the trees were planted.

Plots were either monoculture or mixed-species. In the monocultures, Peltogyne angustiflora Ducke, Centrolobium robustum (Vell.) Mart., Arapatiella psilophylla (Harms.) Cowan, Sclerolobium chrysophyllum Loep, Cordia trichotoma (Vell.) Arrab., or Macrolobium latifolium Vog. were planted in a 2 x 2 m spacing in $144 \mathrm{~m}^{2}$ plots without replication. The mixed-species plot was a combination of the above species together with 57 other native and exotic species, planted in $2 \times 2 \mathrm{~m}$ spacing in a $5,320 \mathrm{~m}^{2}$ plot.
On this large plot, the trees were planted randomly with different numbers of trees for each species. All plots were evaluated after 22 years (August 1994 to July, 1995). To compare the nutrient cycling and soil conditions of these cultivated plots with a more natural condition a $500 \mathrm{~m}^{2}$ control plot was established in an adjacent Dense Primary Natural Ombrophylle Forest and second one in a 40-year-old, secondary, naturally regenerated forest.

\section{Field measurements}

A complete tree diameter inventory was carried out on all plots of the pure and mixed planted species. In the pure plots, standard trees in diameter, stem form and crown were selected to represent the species. In the mixed tree block, trees of similar dimensions for each species were selected. All selected trees were felled and their biomass determined by separating each tree into leaves, branches, bark, and stemwood. Field fresh weight was measured for each component, and a subsample was taken to calculate the dry weight biomass (at $\left.75^{\circ} \mathrm{C}\right)$.

The tree trunk volume was measured based on disks that were cut at four equidistant points along the trunk of the sampled trees. The disk diameter was measured with and without the bark. The tree trunk volume was calculated by the Smallian equation, according to Teixeira (1987). This equation was applied to each tree trunk section. The total tree volume was the sum of the trunk segments. Bark volume was calculated by the difference between the total volume (stemwood + bark) and the stemwood volume. For mixed stand biomass, each species was measured separately (one standard tree per species, as described above).

In all plots, litterfall was assessed every 15 days using $0.25 \mathrm{~m}^{2}$ litter traps placed $0.5 \mathrm{~m}$ above the ground. In each monoculture plot, four traps of $1 \mathrm{~mm}$ mesh polyethylene screen were installed. Twentyfour traps were installed in each mixed stand and primary and secondary forest plots. Four replicate samples of the forest litter in each plot were collected every three months using a $0.25 \mathrm{~m}^{2}$ wooden square frame. To reduce soil contamination, the litter layer material was sequentially sieved with 4,2 , and $1 \mathrm{~mm}$ mesh sieves.

The concentration of $\mathrm{K}$ (flame photometry), $\mathrm{P}$ (colorimetrically with ascorbid acid, Braga \& Defelipo, 1974), and $\mathrm{Ca}$ and $\mathrm{Mg}$ (atomic absorption spectrophotometry) were determined in each tree component, litter layer after wet digestion with nitric and perchloric acids; total Kjeldahl N was determined as described by Bataglia et al. (1983).

In each stand, four composite soil samples were collected from the $0-5$ and $5-10 \mathrm{~cm}$ layers. The soil samples were analyzed for $\mathrm{pH}$ (water), Mehlich-1 extractable $\mathrm{P}$ and $\mathrm{K}$, exchangeable $\mathrm{Ca}$ and $\mathrm{Mg}$, organic $\mathrm{C}$, and total Kjeldahl N according to Defelipo \& Ribeiro (1981) and Tedesco et al. (1985). 


\section{Data analysis}

The trees were evaluated through grouping analysis, in two stages: first, the similarity or dissimilarity of pure and mixed stands was characterized by the standardized Euclidian average distance. Then, groups were formed using Tocher's Method and the graphic dispersion was visualized by the Principal Components (PC), according to Cruz \& Regazzi (1994), based on the plant traits trunk diameter, height and volume as well as biomass and nutrient content of the tree components (leaves, branches, bark, and stemwood). The same procedure was used to evaluate the similarity among the nine forest ecosystems, but only for the nutrient concentration in the tree components. Treatments used in grouping analysis were (1) $P$. angustiflora; (2) C. robustum; (3) A. psilophylla; (4) S. chrysophyllum; (5) C. trichotoma; 6) M. latifolium; (7) mixed-species; (8) secondary forest; and (9) primary forest. The graphic dispersion by the Principal Components also indicated the similarity level of treatments within each group.

The soil data were statistically analyzed using oneway analysis of variance with four replicates, and Tukey's test $(\mathrm{P}<0.05)$. Each forest ecosystem was considered a fixed-effect treatment, according to the procedure described by Lugo et al. (1990).

\section{RESULTS AND DISCUSSION}

\section{Biomass and nutrients}

In general, pure and mixed stands differed in growth characteristics, forming four groups, while the mixed stand constituted an isolated group (Figure 1a, b). The only exception was the tree component biomass of M. latifolium which was similar as in the mixed stand (Figure 1b). Diameter, branches and bark differed most between the two stand systems and contributed to the group formation. The forest species in the mixed stand were taller and higher in volume and total biomass than those in pure stands (Tables 1 and 2) with exception of the $P$. angustiflora stand. The average increase of total biomass in the mixed stand was $29.4 \%$ as compared with the pure stads; A. psilophylla presented the greatest difference $(97.6 \%)$. In the case of $P$. angustiflora, the positive effect of the mixed-species stand was restricted to tree height. In the mixed stand the different tree components increased in the following order: leaf biomass (by a mean $58.4 \%$ ), branches (38.4\%), stemwood (26.5 \%) and bark (17.2\%). The increase in total biomass production in the mixed-species stand is meaningful, since it indicates an increase in the stemwood yield, which is economically the most relevant component.

Nutrient accumulation in the two stand types was dissimilar (Figure 1c). Only C. robustum was statistically similar to the mixed stand. Phosphorus and $\mathrm{Mg}$ contributed most to the dissimilarity between the pure and mixed systems as well as to the group formation. The mixed species accumulated the highest amount of nutrients (17.0\%) in the above-ground biomass (Table 3). The nutrient accumulation of $\mathrm{N}$ differed most between the two systems (40.6\%) and $\mathrm{Mg}(61.3 \%)$ and least for $\mathrm{Ca}(4.3 \%)$. Calcium was the most accumulated nutrient in the above-ground biomass of all species, regardless of the plantation system.
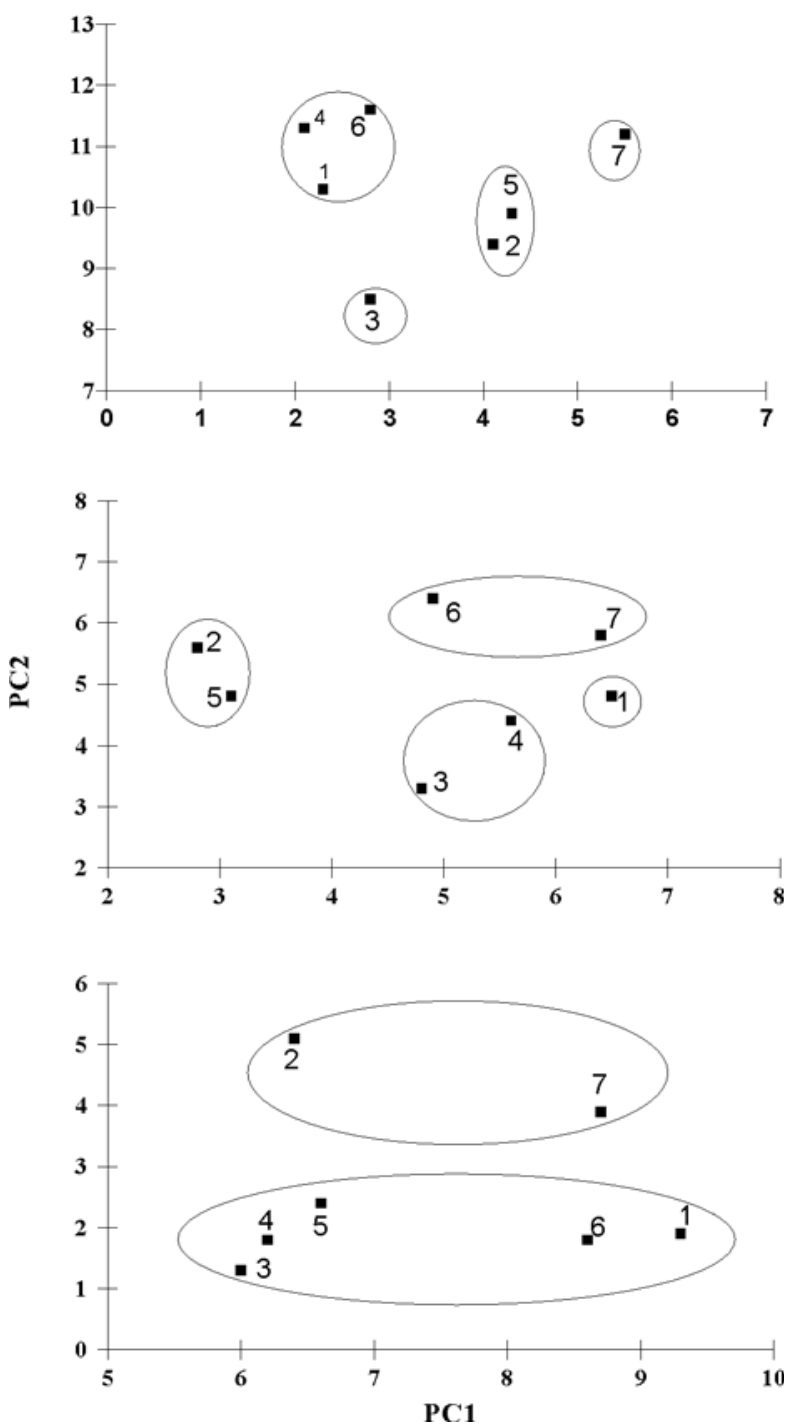

Figure 1. Score dispersion of pure and mixed stands of native forest species based on: (a) height, diameter and tree trunk volume; (b) biomass of leaves, branches, bark and stemwood, and (c) nutrient content (N, P, K, Ca, Mg) in the aboveground biomass as related to principal components (PC1 and PC2) and to grouping by Tocher's Method, based on the standardized Euclidian average distance. 1: $P$. angustiflora, 2: C. robustum, 3: A. psilophylla, 4: S. chrysophyllum, 5: C. trichotoma, 6: M. latifolium and 7: mixedstand. 
Table 1. Diameter at breast height (DBH), total height (TH) and tree stem volume (VOL) of native forest species, in pure $(P)$ and mixed stands $(M)$

\begin{tabular}{|c|c|c|c|c|c|c|}
\hline \multirow{2}{*}{ Species } & \multicolumn{2}{|c|}{ DBH } & \multicolumn{2}{|c|}{ TH } & \multicolumn{2}{|c|}{ VOL } \\
\hline & $\mathbf{P}$ & $\mathbf{M}$ & $\mathbf{P}$ & $\mathbf{M}$ & $\mathbf{P}$ & $\mathbf{M}$ \\
\hline & \multicolumn{2}{|c|}{$\longrightarrow \mathrm{cm}-$} & \multicolumn{2}{|c|}{$-\mathrm{m} \longrightarrow$} & \multicolumn{2}{|c|}{$\mathrm{m}^{3} /$ tree } \\
\hline P. angustiflora & 16.7 & 13.1 & 12.5 & 15.0 & 0.114 & 0.088 \\
\hline C. robustum & 14.6 & 14.6 & 15.5 & 19.8 & 0.125 & 0.179 \\
\hline A. psilophylla & 13.7 & 14.6 & 12.7 & 15.3 & 0.099 & 0.155 \\
\hline S. chrysophyllum & 18.1 & 17.5 & 12.3 & 18.2 & 0.127 & 0.254 \\
\hline C. trichotoma & 14.8 & 16.9 & 15.5 & 19.9 & 0.142 & 0.222 \\
\hline M. latifolium & 16.9 & 18.0 & 11.5 & 16.5 & 0.166 & 0.204 \\
\hline Mean & 15.8 & 15.8 & 13.3 & 17.5 & 0.129 & 0.184 \\
\hline CV (\%) & 9.7 & 11.3 & 11.8 & 11.3 & 16.4 & 28.8 \\
\hline
\end{tabular}

Table 2. Biomass of components of native forest species, in pure (P) and mixed (M) stands

\begin{tabular}{|c|c|c|c|c|c|c|c|c|c|c|}
\hline \multirow{2}{*}{ Species } & \multicolumn{2}{|c|}{ Leaf } & \multicolumn{2}{|c|}{ Branch } & \multicolumn{2}{|c|}{ Bark } & \multicolumn{2}{|c|}{ Bolewood } & \multicolumn{2}{|c|}{ Total } \\
\hline & $\mathbf{P}$ & $\mathbf{M}$ & $\mathbf{P}$ & M & $\mathbf{P}$ & $\mathbf{M}$ & $\mathbf{P}$ & $\mathbf{M}$ & $\mathbf{P}$ & $\mathbf{M}$ \\
\hline & & & & & $\mathrm{kg} / \mathrm{t}$ & ee - & & & 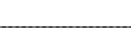 & 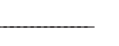 \\
\hline P. angustiflora & 4.96 & 7.32 & 34.00 & 38.92 & 8.12 & 5.68 & 93.20 & 68.96 & 140.28 & 120.88 \\
\hline C. robustum & 3.00 & 2.88 & 11.32 & 11.48 & 14.04 & 16.88 & 60.00 & 81.04 & 88.36 & 112.28 \\
\hline A. psilophylla & 7.28 & 20.08 & 23.04 & 55.24 & 6.28 & 11.12 & 60.04 & 104.52 & 96.64 & 190.96 \\
\hline S. chrysophyllum & 9.76 & 9.64 & 20.88 & 22.36 & 8.76 & 11.80 & 76.12 & 84.36 & 115.48 & 128.16 \\
\hline C. trichotoma & 1.64 & 4.20 & 10.44 & 15.64 & 10.04 & 15.60 & 68.48 & 111.12 & 90.56 & 146.52 \\
\hline M. latifolium & 6.76 & 8.76 & 20.08 & 22.12 & 15.04 & 11.96 & 83.76 & 108.68 & 125.64 & 151.52 \\
\hline Mean & 5.56 & 8.81 & 19.96 & 27.62 & 10.38 & 12.17 & 73.60 & 93.11 & 109.49 & 141.72 \\
\hline CV (\%) & 48.8 & 63.3 & 39.5 & 54.3 & 30.4 & 29.5 & 16.5 & 17.0 & 17.5 & 18.3 \\
\hline
\end{tabular}

Table 3. Nutrient accumulation in the above-ground biomass of native forest species in pure (P) and mixed (M) stands

\begin{tabular}{|c|c|c|c|c|c|c|c|c|c|c|c|c|}
\hline \multirow{2}{*}{ Species } & \multicolumn{2}{|c|}{$\mathbf{N}$} & \multicolumn{2}{|c|}{$\mathbf{P}$} & \multicolumn{2}{|c|}{$\mathbf{K}$} & \multicolumn{2}{|c|}{$\mathbf{C a}$} & \multicolumn{2}{|c|}{ Mg } & \multicolumn{2}{|c|}{ Total } \\
\hline & $\mathbf{P}$ & M & $\mathbf{P}$ & $\mathbf{M}$ & $\mathbf{P}$ & M & $\mathbf{P}$ & $\mathbf{M}$ & $\mathbf{P}$ & $\mathbf{M}$ & $\mathbf{P}$ & M \\
\hline P. angustiflora & 355.3 & 345.2 & 27.4 & 20.9 & 297.2 & 237.0 & 1.188 .7 & 708.4 & 60.8 & 79.7 & 1.929 .4 & 1.391 .2 \\
\hline C. robustum & 387.4 & 389.4 & 13.3 & 15.2 & 129.6 & 176.0 & 1.035 .5 & 1.100 .2 & 123.0 & 179.2 & 1.688 .8 & 1.859 .8 \\
\hline A. psilophylla & 287.1 & 590.2 & 17.7 & 32.3 & 207.5 & 331.9 & 414.0 & 830.6 & 39.6 & 127.1 & 965.9 & 1.912 .1 \\
\hline S. chrysophyllum & 326.4 & 358.4 & 19.8 & 18.0 & 184.8 & 150.3 & 441.0 & 619.2 & 46.5 & 61.6 & 1.018 .5 & 1.207 .4 \\
\hline C. trichotoma & 253.6 & 624.1 & 13.3 & 18.2 & 219.3 & 320.0 & 1.126 .2 & 1.531 .4 & 71.2 & 132.8 & 1.683 .6 & 2.626 .5 \\
\hline M. latifolium & 311.8 & 394.5 & 28.8 & 29.7 & 242.5 & 340.6 & 1.145 .9 & 790.6 & 63.9 & 72.6 & 1.792 .9 & 1.628 .0 \\
\hline Mean & 320.3 & 450.3 & 20.0 & 22.4 & 213.5 & 259.3 & 891.8 & 930.1 & 67.5 & 108.8 & 1.513 .2 & 1.770 .8 \\
\hline $\mathrm{CV}(\%)$ & 13.6 & 25.0 & 30.8 & 28.4 & 24.0 & 29.4 & 37.2 & 33.0 & 40.0 & 38.0 & 25.0 & 25.7 \\
\hline
\end{tabular}


The total nutrient accumulation ranged from 965.9 to $1,929.4 \mathrm{~g}^{\text {tree }}{ }^{-1}$ in pure stands and from $1,207.4$ to $2,626.5 \mathrm{~g} \mathrm{tree}^{-1}$ in the mixed-species stands (Table 3). Nutrient accumulation varied greatly between the tree components (Table 4). Considering all nutrients, the leaves were the component with the greatest difference between the stand systems. However, in absolute terms, the stem would remove the highest amount of nutrients, as it is the target component for harvesting. Nutrient removal in this component is higher in the mixed than in the pure stands. Remarkably, Peltogyne angustiflora produced the least stemwood biomass (Table 2), but accumulated similar or even higher nutrient amounts than the other species, with exception of $\mathrm{N}$ (Table 4). A high Ca content was found in bark and stemwood in both stand systems. In the bark, highest amounts of $\mathrm{N}$ and $\mathrm{Mg}$ were accumulated by Centrolobium robustum. Thus, debarking the trees at the site would be advisable in order to reduce the amount of exported nutrient.

Table 4. Nutrient accumulation in the above-ground components of native forest species, in pure (P) and mixed (M) stands

\begin{tabular}{|c|c|c|c|c|c|c|c|c|}
\hline \multirow{2}{*}{ Species } & \multicolumn{2}{|c|}{ Leaf } & \multicolumn{2}{|c|}{ Branch } & \multicolumn{2}{|c|}{ Bark } & \multicolumn{2}{|c|}{ Stemwood } \\
\hline & $\mathbf{P}$ & M & $\mathbf{P}$ & M & $\mathbf{P}$ & M & $\mathbf{P}$ & M \\
\hline & \multicolumn{7}{|c|}{$\mathrm{g} /$ tree } & \\
\hline P. angustiflora & 47.5 & 96.0 & 159.8 & 159.5 & 45.5 & 27,7 & 102,5 & 62,0 \\
\hline C. robustum & 69.8 & 64.9 & 88.2 & 82.7 & 151.4 & 136,5 & 78,0 & 105,3 \\
\hline A. psilophylla & 88.6 & 289.4 & 78.4 & 127.0 & 30.1 & 58,8 & 90,0 & 115,0 \\
\hline S. chrysophyllum & 132.6 & 113.7 & 58.5 & 89.4 & 51.6 & 62,5 & 83,7 & 92,8 \\
\hline C. trichotoma & 34.2 & 70.8 & 51.2 & 109.4 & 79.2 & 199,5 & 89,0 & 244,4 \\
\hline M. latifolium & 95.0 & 138.6 & 56.2 & 46.4 & 102.0 & 68,2 & 58,6 & 141,3 \\
\hline Mean & 77.9 & 128.9 & 82.0 & 102.4 & 76,6 & 92,2 & 83,6 & 126,8 \\
\hline \multirow[t]{2}{*}{ CV (\%) } & 41.6 & 58.9 & 45.3 & 34.8 & 53.3 & 62.9 & 16.1 & 45.5 \\
\hline & \multicolumn{8}{|c|}{$\mathrm{P}$} \\
\hline P. angustiflora & 1.9 & 3.1 & 10.2 & 7.4 & 1.3 & 0.8 & 14.0 & 9.6 \\
\hline C. robustum & 2.6 & 3.3 & 2.7 & 3.3 & 2.6 & 2.9 & 5.4 & 5.7 \\
\hline A. psilophylla & 3.6 & 9.4 & 6.4 & 11.0 & 1.1 & 1.5 & 6.6 & 10.4 \\
\hline S. chrysophyllum & 4.7 & 4.5 & 5.4 & 4.2 & 2.1 & 2.6 & 7.6 & 6.7 \\
\hline C. trichotoma & 2.2 & 3.2 & 2.9 & 3.6 & 2.0 & 2.5 & 6.2 & 8.9 \\
\hline M. latifolium & 4.9 & 7.3 & 6.4 & 4.6 & 3.3 & 2.6 & 14.2 & 15.2 \\
\hline Mean & 3.3 & 5.1 & 5.6 & 5.6 & 2.0 & 2.1 & 9.0 & 9.4 \\
\hline \multirow[t]{2}{*}{ CV (\%) } & 3.6 & 47.0 & 45.0 & 48.7 & 37.3 & 35.5 & 40.7 & 32.5 \\
\hline & \multicolumn{8}{|c|}{$\mathrm{K}$} \\
\hline P. angustiflora & 38.1 & 41.0 & 111.9 & 93.4 & 26.0 & 13.0 & 121.2 & 89.6 \\
\hline C. robustum & 28.0 & 33.6 & 26.0 & 36.8 & 33.6 & 48.9 & 42.0 & 56.7 \\
\hline A. psilophylla & 57.3 & 130.6 & 69.2 & 88.3 & 15.0 & 18.9 & 66.0 & 94.1 \\
\hline S. chrysophyllum & 73.1 & 47.2 & 41.8 & 31.3 & 16.6 & 21.2 & 53.3 & 50.6 \\
\hline C. trichotoma & 26.7 & 55.7 & 39.7 & 84.4 & 57.1 & 57.7 & 95.8 & 122.2 \\
\hline M. latifolium & 47.3 & 75.4 & 54.2 & 64.1 & 40.5 & 49.0 & 100.5 & 152.1 \\
\hline Mean & 45.0 & 63.9 & 57.1 & 66.4 & 31.4 & 34.8 & 79.8 & 94.2 \\
\hline \multirow[t]{2}{*}{ CV (\%) } & 36.5 & 51.0 & 48.8 & 37.1 & 46.2 & 50.3 & 35.1 & 37.4 \\
\hline & \multicolumn{8}{|c|}{$\mathrm{Ca}$} \\
\hline P. angustiflora & 118.8 & 113.6 & 635.8 & 350.2 & 294.3 & 127.4 & 139.8 & 117.2 \\
\hline C. robustum & 28.6 & 17.2 & 211.5 & 155.1 & 315.4 & 441.7 & 480.0 & 486.2 \\
\hline A. psilophylla & 32.7 & 150.7 & 62.3 & 287.1 & 132.9 & 194.2 & 186.1 & 198.6 \\
\hline S. chrysophyllum & 73.1 & 81.9 & 106.5 & 178.8 & 185.3 & 265.7 & 76.1 & 92.8 \\
\hline C. trichotoma & 31.0 & 64.9 & 109.6 & 218.8 & 437.9 & 525.4 & 547.7 & 722.3 \\
\hline M. latifolium & 54.1 & 127.2 & 251.0 & 108.3 & 338.2 & 283.4 & 502.6 & 271.7 \\
\hline Mean & 56.3 & 92.6 & 229.4 & 216.4 & 284.0 & 306.3 & 322.0 & 314.8 \\
\hline \multirow[t]{2}{*}{ CV (\%) } & 56.9 & 47.4 & 84.1 & 37.6 & 35.3 & 44.8 & 59.6 & 70.9 \\
\hline & \multicolumn{8}{|c|}{$\mathrm{Mg}$} \\
\hline P. angustiflora & 13.4 & 27.8 & 27.2 & 27.2 & 1.6 & 4.0 & 18.6 & 20.7 \\
\hline C. robustum & 9.9 & 13.5 & 36.2 & 57.4 & 58.9 & 75.9 & 18.0 & 32.4 \\
\hline A. psilophylla & 12.3 & 40.2 & 11.5 & 22.1 & 3.8 & 54.4 & 12.0 & 10.4 \\
\hline S. chrysophyllum & 13.6 & 24.1 & 12.5 & 13.4 & 5.2 & 7.1 & 15.2 & 16.9 \\
\hline C. trichotoma & 9.8 & 23.0 & 13.6 & 31.3 & 34.1 & 45.2 & 13.7 & 33.3 \\
\hline M. latifolium & 19.6 & 31.5 & 20.1 & 11.0 & 7.5 & 8.4 & 16.7 & 21.7 \\
\hline Mean & 13.1 & 26.6 & 20.1 & 27.0 & 18.5 & 32.5 & 15.7 & 22.6 \\
\hline $\mathrm{CV}(\%)$ & 25.0 & 30.7 & 44.7 & 56.7 & 114.1 & 84.8 & 14.9 & 36.0 \\
\hline
\end{tabular}


In our study, nutrient concentrations varied among species and were also affected by the stand systems (Table 5). In comparison with pure stands, the sum of all nutrients was generally lower in species in the mixed stand, mainly due to the behavior of $P$. angustiflora, C. robustum and M. latifolium. However, the ranking of the nutrient requirement of the different species was not affected by the plantation system. Centrolobium robustum and $C$. trichotoma were the most demanding species, followed by $P$. angustiflora, $M$. latifolium, A. psilophylla, and S. chrysophyllum.

In the mixed stand, the greatest reduction in mean nutrient concentration was observed for $\mathrm{Ca}(-18.8 \%)$, while $\mathrm{Mg}$ increased (+23.1\%). Centrolobium robustum had the highest $\mathrm{N}$ and $\mathrm{Mg}$ mean concentrations (Table 5). The highest ratio of $\mathrm{N}$ by biomass in this species may be explained by its $\mathrm{N}$ fixing capacity (Montagnini et al., 1994a). Nevertheless, there was an increase in the mean $\mathrm{N}$ concentration of Cordia trichotoma in the mixed stand. All species were Ca-demanding, followed by $\mathrm{N}, \mathrm{K}, \mathrm{Mg}$, and $\mathrm{P}$. The reduction in mean total nutrient concentrations in mixed-stand trees led to a high nutrient use efficiency (NUE) for stem production (Table 5). Thus, the relative nutrient removal would be lower in the mixed than in the pure stands. These results indicate that the ecophysiological attributes of the species are optimized in a more heterogeneous system, resulting in a higher NUE for biomass productivity.

There were few differences in nutrient concentration between mixed, secondary, and primary forest ecosystems (Table 6). The secondary forest had the highest $\mathrm{P}$ concentration in all plant components but stemwood, while the primary as well as the secondary forest presented higher Ca concentration in the bark, compared with mixed stands. From a nutritional point of view, the mixed stand was quite similar to a natural ecosystem, constituting an isolated group (Figure 2). However, the three heterogeneous ecosystems were dissimilar to the pure stands.

Table 5. Weighted average nutrient concentration in above-ground biomass and nutrient use efficiency (NUE) for stem production of native forest species, in pure (P) and mixed (M) stands

\begin{tabular}{|c|c|c|c|c|c|c|c|c|c|c|c|c|c|c|}
\hline \multirow{2}{*}{ Species } & \multicolumn{2}{|c|}{$\mathbf{N}$} & \multicolumn{2}{|c|}{$\mathbf{P}$} & \multicolumn{2}{|c|}{$\mathbf{K}$} & \multicolumn{2}{|c|}{$\mathbf{C a}$} & \multicolumn{2}{|c|}{ Mg } & \multicolumn{2}{|c|}{ Total } & \multicolumn{2}{|c|}{ NUE } \\
\hline & $\mathbf{P}$ & M & $\mathbf{P}$ & $\mathbf{M}$ & $\mathbf{P}$ & M & $\mathbf{P}$ & $\mathbf{M}$ & $\mathbf{P}$ & M & $\mathbf{P}$ & M & $\mathbf{P}$ & $\mathbf{M}$ \\
\hline & & & & & & $\mathrm{g} \mathrm{k}^{-}$ & $g^{-1}-$ & & & & & & \multicolumn{2}{|c|}{$-\mathrm{g} \mathrm{g}^{-1}$} \\
\hline P. angustiflora & 2.53 & 2.86 & 0.20 & 0.17 & 2.12 & 1.96 & 8.47 & 5.86 & 0.43 & 0.66 & 13.8 & 11.5 & 132 & 158 \\
\hline C. robustum & 4.38 & 3.47 & 0.15 & 0.14 & 1.47 & 1.57 & 11.71 & 9.80 & 1.39 & 1.60 & 19.1 & 16.6 & 62 & 70 \\
\hline A. psilophylla & 2.97 & 3.10 & 0.18 & 0.17 & 2.15 & 1.74 & 4.28 & 4.35 & 0.41 & 0.67 & 10.0 & 10.0 & 122 & 153 \\
\hline S. chrysophyllum & 2.83 & 2.80 & 0.17 & 0.14 & 1.60 & 1.17 & 3.82 & 4.83 & 0.40 & 0.48 & 8.8 & 9.4 & 171 & 155 \\
\hline C. trichotoma & 2.80 & 4.26 & 0.15 & 0.12 & 2.42 & 2.18 & 12.43 & 10.45 & 0.79 & 0.91 & 18.6 & 17.9 & 58 & 65 \\
\hline M. latifolium & 2.48 & 2.60 & 0.23 & 0.20 & 1.93 & 2.25 & 9.12 & 5.22 & 0.51 & 0.48 & 14.3 & 10.7 & 83 & 119 \\
\hline Mean & 3.00 & 3.18 & 0.18 & 0.16 & 1.95 & 1.81 & 8.31 & 6.75 & 0.65 & 0.80 & 14.1 & 12.7 & 105 & 120 \\
\hline CV (\%) & 21.4 & 17.4 & 15.7 & 16.4 & 16.8 & 20.5 & 39.8 & 36.1 & 54.6 & 48.2 & 27.5 & 26.1 & 38.7 & 32. \\
\hline
\end{tabular}

Table 6. Nutrient concentration in the above-ground components of the mixed-species stand, secondary forest and primary forest

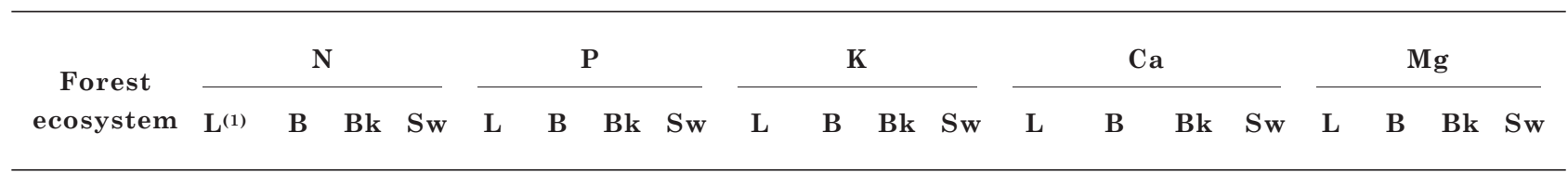

\begin{tabular}{|c|c|c|c|c|c|c|c|c|c|c|c|c|c|c|c|c|c|c|c|c|}
\hline $\begin{array}{l}\text { Mixed- } \\
\text { stand }\end{array}$ & 18.5 & 8.6 & 7.3 & 2.2 & 1.0 & 0.4 & 0.9 & 1.6 & 10.0 & 6.2 & 4.1 & 1.9 & 15.9 & 18.0 & 17.0 & 3.0 & 3.9 & 2.0 & 0.9 & 0.6 \\
\hline S. forest & 12.9 & 8.4 & 4.7 & 2.2 & 1.3 & 2.1 & 1.8 & 0.1 & 8.7 & 6.5 & 4.1 & 2.0 & 15.4 & 18.2 & 29.9 & 3.1 & 3.9 & 3.6 & 0.9 & 0.5 \\
\hline P. forest & 16.3 & 8.6 & 6.8 & 2.2 & 0.7 & 0.3 & 0.6 & 0.3 & 11.8 & 5.9 & 4.7 & 1.6 & 15.3 & 18.0 & 30.5 & 2.9 & 4.5 & 2.3 & 1.1 & 0.5 \\
\hline
\end{tabular}

${ }^{(1)} \mathrm{L}=$ leaf, $\mathrm{B}=$ branch, $\mathrm{Bk}=$ bark, $\mathrm{Sw}=$ stemwood. 


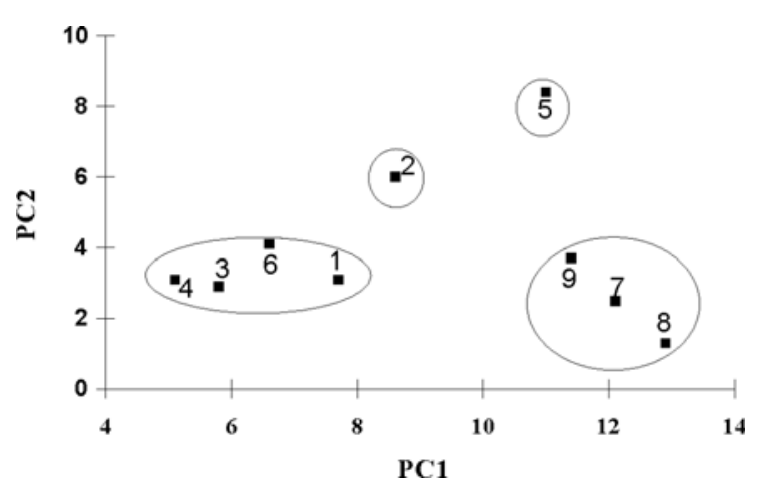

Figure 2. Score dispersion of pure stands, mixed stands, secondary forest and primary forest, derived from the nutrient concentration $(\mathrm{N}, \mathrm{P}$, $\mathrm{K}, \mathrm{Ca}$ and $\mathrm{Mg}$ ) of leaves, branches, bark and stemwood, when related to the principal components (PC1 and PC2) and to the grouping by Tocher's Method, based on standardized Euclidian average distance. 1: $P$. angustiflora, 2: C. robustum, 3: A. psilophylla, 4: S. chrysophyllum, 5: C. trichotoma, 6: M. latifolium, and heterogeneous ecosystems by 7: mixedstand, 8: secondary forest and 9: primary forest.

\section{Litter and litter layer nutrient content}

The seasonality of litterfall varied among the species (Figure 3). This seasonality is responsible for a relatively constant litterfall rate in natural tropical ecosystems (Vinha \& Pereira, 1983), which was confirmed by the analysis of litterfall in the mixedspecies stand. Variability in the mixed-species stand (CV $31.2 \%$ ) was lower than in the pure-species stand (CV 44.7 to $91.4 \%$ ), with exception of $C$. trichotoma (CV $29.1 \%$ ). The highest litterfall variation (57.8\%) observed in the primary forest was probably due to the greater contribution from dominant trees (wider crown) in this ecosystem (Figure 3). Secondary forests are more homogeneous in diameter and height than primary forests (Linden et al., 1988). The structure of a mixed-species stand is similar to secondary forest (data not presented). Consequently, the more uniform litterfall in heterogeneous ecosystems would be more related to the homogeneity level of its structure than to the number of species.

The greatest litterfall was measured in the primary forest $\left(9.3 \mathrm{Mg} \mathrm{ha}^{-1}\right)$, followed by mixed-species stand (7.6 Mg ha-1) and secondary forest (7.3 $\left.\mathrm{Mg} \mathrm{ha}^{-1}\right)$.The highest and lowest litterfall in pure stands were observed with $A$. psilophylla $\left(9.1 \mathrm{Mg} \mathrm{ha}^{-1}\right)$ and $C$. robustum (5.5 Mg ha-1), respectively (Figure 4). The annual nutrient return via litter varied widely among forest ecosystems (Figure 5). On average, the transfer rate was highest for $\mathrm{N}$, followed by $\mathrm{Ca}, \mathrm{K}, \mathrm{Mg}$, and $\mathrm{P}$. For this nutrient, the rate in the mixed-species stand was higher than in the pure stands and secondary forest. Exceptions were A. psilophylla and the primary forest.

Differences in accumulation and amount of litter layer nutrients were also detected among ecosystems
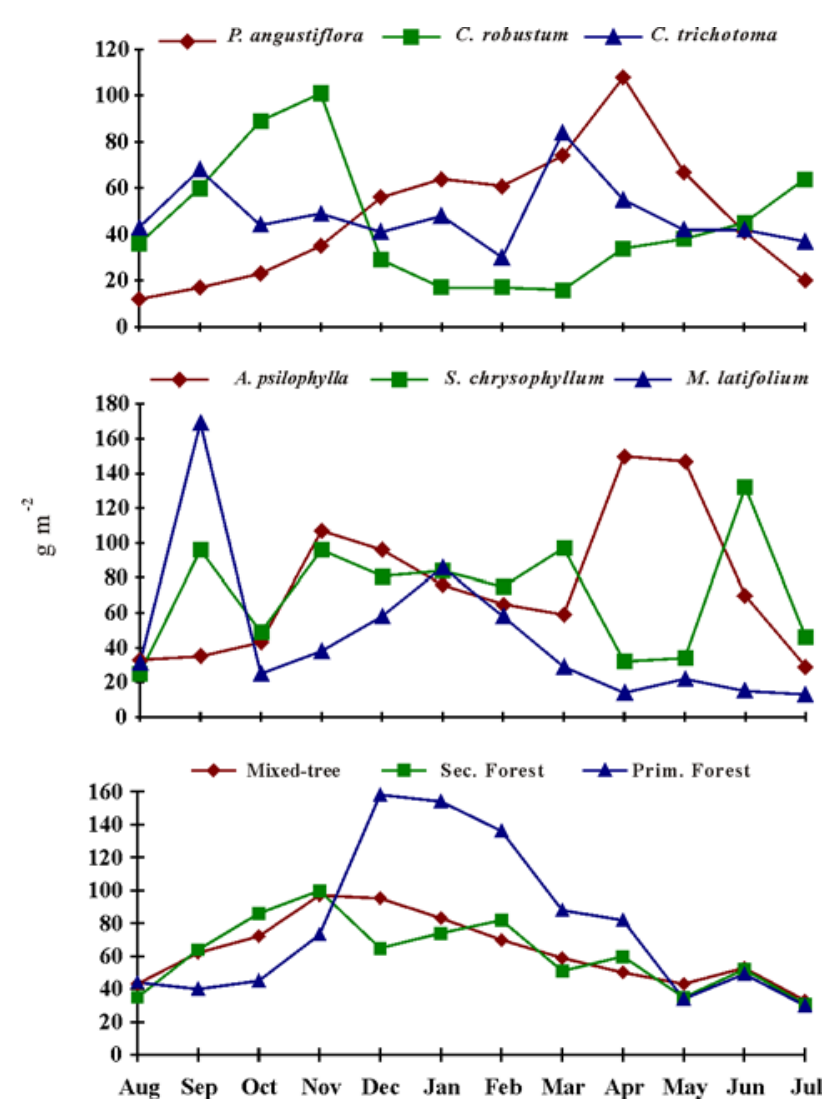

Figure 3. Litterfall of native species in pure and mixed stands, secondary forest and primary forest, from August 1994 through July 1995.

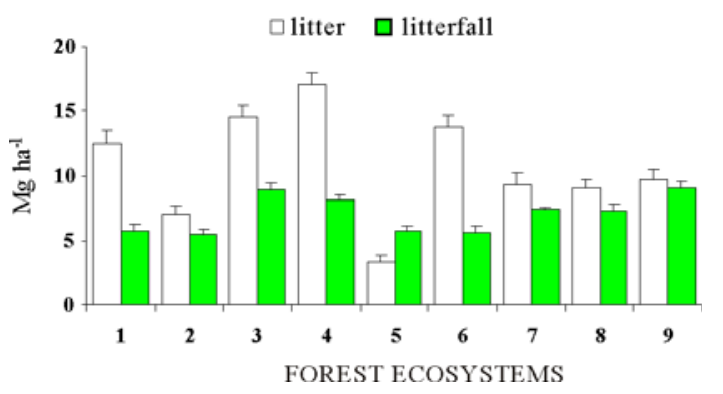

Figure 4. Total litterfall and litter layer nutrient contents accumulated in different forest ecosystems in the coastal tablelands of southeastern Bahia (August, 1994 through July, 1995). 1: P. angustiflora, 2: C. robustum, 3: A. psilophylla, 4: S. chrysophyllum, 5: C. trichotoma, 6: M. latifolium, 7: mixed-stand, 8: secondary forest and 9: primary forest. Vertical bars indicate standard error.

(Figure 5). Leaves accounted for over $90 \%$ of the litter layer mass in all forest ecosystems (data not shown). Apart from C. trichotoma and C. robustum, pure stands accumulated more litter than the mixed-tree stand, secondary forest, and primary forest (Figure 4). Since these three ecosystems had high litterfall rates (Figure 4), the decomposition rate should be higher in the more diverse ecosystems, enhancing nutrient 
cycling (Figure 5). This was evidenced by the estimated litter turnover rate ( $k$ - values) (Anderson \& Ingram, 1989) and by the Mean Residence Time (MRT) of nutrients (Adams \& Attiwill, 1986) in the litter layer in these ecosystems (Table 7). The mixedspecies stand, secondary forest and primary forest had higher litter turnover rates ( $k$ - values) than pure stands, with exception of C. trichotoma, and the lowest values of MRT, particularly for N, P, Ca and Mg. However, the estimated MRT value must be interpreted as an indicator of nutrient turnover rate, or of mineralization potential, due to the possibility of immobilization during the decomposition process (Adams and Attiwill, 1986).

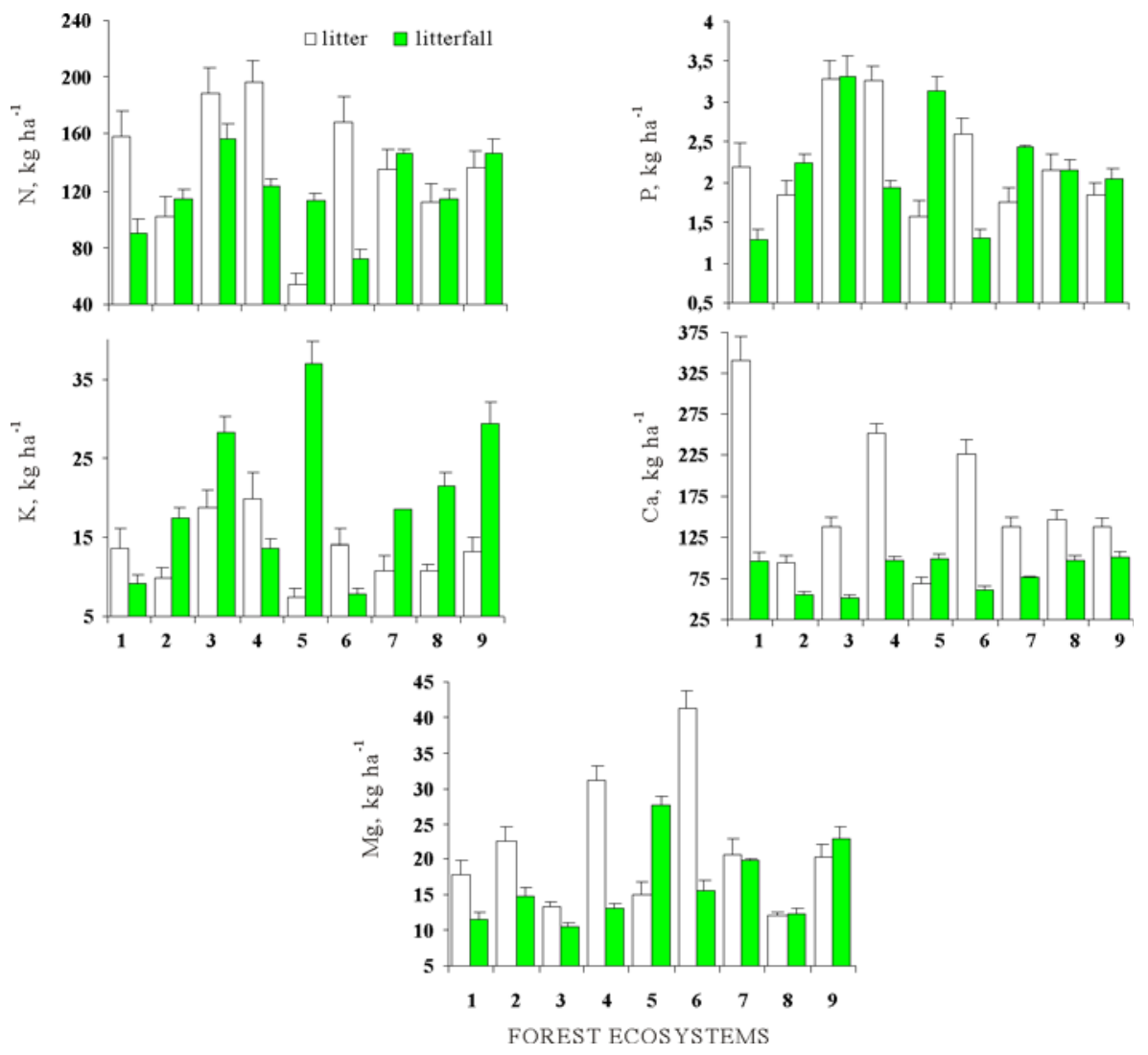

Figure 5. Annual amount (August, 1994 through July, 1995) of N, P, K, Ca and Mg in litterfall and accumulated in the litter layer of different forest ecosystems, in the coastal tablelands of southeastern Bahia. 1: $P$. angustiflora, 2: C. robustum, 3: A. psilophylla, 4: S. chrysophyllum, 5: C. trichotoma, 6: M. latifolium, 7: mixed-stand, 8: secondary forest and 9: primary forest. Vertical bars indicate standard error.

Table 7. Litter turnover rates ( $k$ - values) and mean residence time of nutrients (MRT) in different forest cover types

\begin{tabular}{|c|c|c|c|c|c|c|}
\hline Covers & $k$ & $\mathbf{N}$ & $\mathbf{P}$ & $\mathbf{K}$ & $\mathbf{C a}$ & $\mathrm{Mg}$ \\
\hline \multicolumn{7}{|c|}{ TMR (year) } \\
\hline$P$. angustiflora & 0.46 & 1.73 & 1.69 & 0.14 & 3.47 & 1.50 \\
\hline C. robustum & 0.78 & 0.86 & 0.78 & 0.54 & 1.71 & 1.53 \\
\hline A. psilophylla & 0.63 & 1.20 & 0.97 & 0.66 & 2.65 & 1.18 \\
\hline S. chrysophyllum & 0.49 & 1.54 & 1.65 & 1.43 & 2.49 & 2.21 \\
\hline C. trichotoma & 1.62 & 0.51 & 0.53 & 0.21 & 0.72 & 0.57 \\
\hline M. latifolium & 0.41 & 2.32 & 2.00 & 1.75 & 3.66 & 2.56 \\
\hline Mixed-tree & 0.82 & 0.89 & 0.72 & 0.55 & 1.71 & 1.00 \\
\hline Secondary forest & 0.81 & 0.95 & 1.00 & 0.50 & 1.51 & 1.00 \\
\hline Primary forest & 0.96 & 0.90 & 0.90 & 0.42 & 1.29 & 0.83 \\
\hline
\end{tabular}

$k$ values = leaf litterfall mass/leaf litter layer mass. MRT = quantity of litter layer nutrient/quantity of litterfall nutrient. 


\section{Chemical soil attributes}

The soil fertility level was low in all ecosystems. The most significant changes in the secondary and primary forests were the altered $\mathrm{pH}$ value and $\mathrm{Ca}$ content in the $0-5 \mathrm{~cm}$ soil layer (Table 8). These differences were probably due to the rates of nutrient transfer through litterfall and decomposition (Table 7 and Figure 5). Peltogyne angustiflora, S. chrysophyllum, and $C$. trichotoma in pure stands are noteworthy since they resulted in the highest $\mathrm{pH}$ and Ca levels, although $\mathrm{Ca}$ had been the most accumulated nutrient in the above-ground biomass (Table 3). Macrolobium latifolium also presented high $\mathrm{Ca}$ accumulation in its biomass; however, the soil $\mathrm{pH}$ values and $\mathrm{Ca}$ content were lower than in the secondary and primary forest (Tables 3 and 8). Similarly, high Mg in C. robustum biomass did not correspond to higher contents of this nutrient in the soil (Tables 3 and 8). Cordia trichotoma was the only species with significantly higher $\mathrm{P}$ and $\mathrm{K}$ contents than in the secondary and primary forest in the $0-10 \mathrm{~cm}$ soil layer (Table 8). There were few differences among ecosystems regarding $\mathrm{N}$ content, regardless of the $\mathrm{N}$-fixing capacity of $C$. robustum. In pure stands, the soil fertility level was highest under $C$. trichotoma, probably due to the highest nutrient transfer rate through litterfall and low turnover rate ( $k$ - values), and the lowest MRT for nutrients of this species (Table 7 and Figure 5). The pure and mixed-species stands as well as secondary forest had higher soil organic $\mathrm{C}$ in the $0-5 \mathrm{~cm}$ layer than the primary forest ecosystem.

The mixed-species stand represents an intermediate nutritional situation between the primary forest and pure stand systems. Results in Tables 3, 5, 7, and 8 indicate a complementary role of the species in a mixed stand and that the higher soil fertility would supply the species' nutritional demands. The complementary role is given by the different rates of nutrient uptake and nutrient transfer through litterfall. For example, C. robustum accumulated highest $\mathrm{Mg}$ amounts in both stand systems (Table 3), but this high Mg demand would be satisfied by other species that enrich the soil with this nutrient (Table 8). Therefore, this complementary

Table 8. pH values, and soil C, N, P, K, Ca and Mg levels under different forest ecosystems

\begin{tabular}{|c|c|c|c|c|c|c|c|c|c|c|c|}
\hline \multirow{2}{*}{ Depth } & \multicolumn{9}{|c|}{ Forest ecosystems ${ }^{(1)}$} & \multirow{2}{*}{ Tukei } & \multirow{2}{*}{ CV (\%) } \\
\hline & 1 & 2 & 3 & 4 & 5 & 6 & 7 & 8 & 9 & & \\
\hline \multirow[t]{2}{*}{$\mathrm{cm}$} & & & & & & & & & & $(\mathrm{P}<0,05)$ & \\
\hline & \multicolumn{11}{|c|}{$\mathrm{pH}$} \\
\hline $0-5$ & 6.2 & 5.3 & 5.2 & 6.1 & 6.1 & 4.8 & 5.6 & 5.2 & 5.5 & 0.6 & 5.1 \\
\hline \multirow[t]{2}{*}{$5-10$} & 5.4 & 4.9 & 5.0 & 5.5 & 5.7 & 4.8 & 5.4 & 4.9 & 5.3 & 0.6 & 5.2 \\
\hline & \multicolumn{11}{|c|}{$\mathrm{C}\left(\mathrm{g} \mathrm{kg}^{-1}\right)$} \\
\hline $0-5$ & 33.9 & 26.0 & 30.7 & 28.6 & 37.8 & 35.9 & 39.5 & 25.6 & 19.1 & 16.9 & 26.1 \\
\hline \multirow[t]{2}{*}{$5-10$} & 23.2 & 21.6 & 23.4 & 21.2 & 30.7 & 26.1 & 28.3 & 17.8 & 11.8 & 14.3 & 27.2 \\
\hline & \multicolumn{11}{|c|}{$\mathrm{N}\left(\mathrm{g} \mathrm{kg}^{-1}\right)$} \\
\hline $0-5$ & 1.68 & 1.35 & 1.53 & 1.53 & 1.98 & 1.38 & 1.68 & 1.40 & 1.18 & 0.55 & 18.4 \\
\hline \multirow[t]{2}{*}{$5-10$} & 1.40 & 1.33 & 1.28 & 1.28 & 1.55 & 1.13 & 1.45 & 1.18 & 0.88 & 0.42 & 13.9 \\
\hline & \multicolumn{11}{|c|}{$\mathrm{P}\left(\mathrm{mg} \mathrm{dm} \mathrm{m}^{-3}\right)$} \\
\hline $0-5$ & 1.5 & 2.6 & 2.5 & 2.1 & 3.4 & 1.8 & 2.1 & 1.3 & 1.6 & 0.7 & 15.3 \\
\hline \multirow[t]{2}{*}{$5-10$} & 1.1 & 1.6 & 1.7 & 1.5 & 2.2 & 1.5 & 1.7 & 0.8 & 1.3 & 0.5 & 15.3 \\
\hline & \multicolumn{11}{|c|}{$\mathrm{K}(\mathrm{mg} \mathrm{dm}-3)$} \\
\hline $0-5$ & 31 & 35 & 52 & 31 & 72 & 33 & 35 & 34 & 35 & 19 & 21.0 \\
\hline \multirow[t]{2}{*}{$5-10$} & 17 & 21 & 32 & 19 & 53 & 22 & 25 & 22 & 23 & 15 & 25.2 \\
\hline & \multicolumn{11}{|c|}{$\mathrm{Ca}\left(\mathrm{cmol}_{\mathrm{c}} \mathrm{dm}^{-3}\right)$} \\
\hline $0-5$ & 3.55 & 1.23 & 1.03 & 3.25 & 2.80 & 0.43 & 2.58 & 1.40 & 1.78 & 1.25 & 30.9 \\
\hline \multirow[t]{2}{*}{$5-10$} & 1.28 & 0.50 & 0.70 & 1.68 & 1.93 & 0.23 & 1.50 & 0.80 & 1.10 & 0.95 & 37.2 \\
\hline & \multicolumn{11}{|c|}{$\mathrm{Mg}\left(\mathrm{cmol}_{\mathrm{c}} \mathrm{dm}^{-3}\right)$} \\
\hline $0-5$ & 1.03 & 0.68 & 0.85 & 1.45 & 1.53 & 0.93 & 1.25 & 0.60 & 0.70 & 0.41 & 17.8 \\
\hline $5-10$ & 0.65 & 0.30 & 0.73 & 0.98 & 1.08 & 0.65 & 0.85 & 0.45 & 0.48 & 0.39 & 24.1 \\
\hline
\end{tabular}

(1) 1: P. angustiflora, 2: C. robustum, 3: A. psilophylla, 4: S. chrysophyllum, 5: C. trichotoma, 6: M. latifolium, 7: mixed-stand, 8: secondary forest and 9: primary forest. 
role in mixed stands would result in a higher growth of the species owing to a nutritionally more balanced system than in pure stands.

In this tropical region of low-fertility soils, growth and yield of native forest species are higher in mixed than in pure stands. Among the reasons that explain the improved growth of these species in mixed stands are the relatively constant litterfall rate throughout the year, the variable rates of nutrient transfer through litterfall, the diverse quality of the litter components leading to a more uniform decomposition rate; and the complementary role of the different species in nutrient uptake, resulting in improved soil fertility.

In pure stands, nutrient cycling is restricted to the litter of the planted species. The eventual slow litter decomposition of one particular species would diminish the nutrient cycling rate, which would affect tree growth.

Montagnini et al. (1994a) evaluated edaphic alterations under the influence of native species in 15-year-old pure and mixed-tree stands of the species A. psilophylla, C. robustum, and M. latifolium. In a comparison of their results with those found here for the same species in both stand systems, it was observed that the main alteration here was the improved soil fertility in the $0-5 \mathrm{~cm}$ layer, apart from $\mathrm{N}$. This demonstrates a temporal effect of the type of forest ecosystem on soil fertility.

The continuous litterfall rate in the mixed-species stand is a collective property of the trees on the site. The decomposition rate of the litter layer represents an emergent property, due to the interaction of decomposition processes of its components and not only to the total sum of the individual rates of the species (Gama-Rodrigues et al., 2003). Therefore, a mixedspecies stand reproduces a complex of interactions of a natural forest. In such ecosystems, collective and emergent properties are manifested simultaneously (Salt, 1979; Odum, 1983; Yost et al., 1997).

In a 7-year-old mixed-species stand Garrido \& Poggiani (1982) verified that uniform litterfall rates enable a more effective soil cover. They worked with the native Atlantic Forest species Anadenanthera falcata, Myracrodruon urundeuva, Gochnatia polymorpha and Tabebuia impetiginosa of the southeastern region of Brazil. Similar results were found for a 3-year-old mixed-tree stand of native Atlantic Forest species of Lowlands in Costa Rica (Montagnini et al., 1994b). In this study a continuous litterfall rate resulted in larger diameter, height and above-ground biomass. Moreover, the mixed stand was economically more advantageous than the pure stands (Montagnini et al., 1994b). In Hawaii, in a 6year-old mixed-tree stand of Eucalyptus salignal Albizia falcataria (34/66 \%), biomass production was higher than in pure stands of these species, due to a more efficient nutrient use and cycling (Binkley et al., 1992). In contrast, Silva \& Vinha (1991) did not state any differences in tree height of the native species Arapatiella psilophylla, Bombax macrophyllum, Bowdichia virgilioides and the exotic Gmelina arborea between pure and mixed stand systems, on the tablelands of southeastern Bahia, Brazil.

The hypothesis of the current study needs to be tested experimentally, since the effect of mixed-tree stands on the growth and nutrient accumulation of the 57 other species in this stand system has not been estimated. Moreover, the relative contribution of each species to the biomass and nutrient transfer rate through litterfall needs to be measured.

Priority for the implantation of a mixed-species stand is the combination of species with complementary ecophysiological attributes, such as species with high nutrient cycling rates together with species of high nutrient use efficiency.

\section{CONCLUSIONS}

Native species in both pure and mixed stand systems influence soil fertility levels differently from secondary and primary forest ecosystems. Growth and yield in mixed-tree stands were higher than in pure stands owing to the combination of species with complementary ecophysiological attributes, consequently improving the efficiency in nutrient use and cycling. Mixed-tree stands would represent an ecologically more sustainable production system.

\section{LITERATURE CITED}

ADAMS, A.M. \& ATTIWILL, P.M. Nutrient cycling and nitrogen mineralization in eucalypt forests of south-eastern Australia. I. Nutrient cycling and nitrogen turnover. Plant Soil, 92:319-339, 1986

ANDERSON, J.N. \& INGRAM, J.S.I.. Tropical soil biology and fertility: A handbook of methods. Wallingford, $\mathrm{CAB}$ International, 1989. $171 \mathrm{p}$

BATAGLIA, O.C.; FURLANI, A.M.C.; TEIXEIRA, J.P.F.; FURLANI, P.R. \& GALLO, J.R. Métodos de análise química de plantas. Campinas, Instituto Agronômico, 1983. 48p. (Boletim Técnico, 78)

BINKLEY, D.; DUNKIN, K.A.; DEBELL, D. \& RYAN, M.G. Production and nutrient cycling in mixed plantations of Eucalyptus and Albizia in Hawaii. For. Sci., 38:393-408, 1992

BRAGA, J.M. \& DEFELIPO, B.V. Determinação espectrofotométrica de fósforo em extrato de solo e material vegetal. R. Ceres, 21:73-85, 1974.

CORRÊA, F. A reserva da biosfera da mata atlântica. São Paulo, 1996. 27p. (Caderno, 2 / Série Cadernos da Reserva da Biosfera da Mata Atlântica)

CRUZ, C.D. \& REGAZZI, A.J. Modelos biométricos aplicados ao melhoramento genético. Viçosa, MG, Universidade Federal de Viçosa, 1994. 390p. 
DEFELIPO, B.V. \& RIBEIRO, A.C. Análise química do solo. Viçosa, MG, Universidade Federal de Viçosa, 1981. 17p. (Boletim de Extensão, 29)

GAMA-RODRIGUES, A.C.; BARROS, N.F. \& SANTOS, M.L. Decomposição e liberação de nutrientes do folhedo de espécies florestais nativas em plantios puros e mistos no sudeste da Bahia. R. Bras. Ci. Solo, 27:1021-1031, 2003.

GARRIDO, M.A.O. \& POGGIANI, F. Avaliação da quantidade e do conteúdo de nutrientes do folhedo de alguns povoamentos puros e misto de espécies indígenas. Silvicultura. São Paulo, 15/16:1-22, 1982.

LEÃO, A.C. \& MELO, A.A.O. Características morfológicas, físico-químicas e mineralógicas dos solos da Estação Ecológica do Pau-Brasil, Porto Seguro, Bahia. Agrotrópica, $2: 105-112,1990$

LEÃO, A.C. \& SILVA, L.A.M. Bioelementos na cobertura vegetal e no solo do ecossistema dos tabuleiros costeiro do sudeste da Bahia, Brasil. Agrotrópica, 3:87-92, 1991.

LUGO, A.E.; CUEVAS, E. \& SANCHEZ, M.J. Nutrients and mass in litter and soil of ten tropical tree plantations. Plant Soil, 125:263-280, 1990.

MONTAGNINI, F.; FANZERES, A. \& VINHA, S.G. Studies on restoration ecology in the Atlantic forest region of Bahia, Brasil. Interciencia, 19:323-330, 1994a.

MONTAGNINI, F.; GONZÁLEZ, E.; PORRAS, C.; RHEINGANS R. \& SANCHO, F. Mixed-tree plantations in the humid tropics: Growth, litterfall and economics of experimental systems in Latin America. In: IUFRO INTERNATIONAL SYMPOSIUM ON GROWTH AND YIELD OF TROPICAL FORESTS, Tokyo, 1994. Proceedings. Tokyo, University of Agriculture and Technology, 1994b. p.125-135

MORI, S.A. \& SILVA; L.A.M. O herbário do Centro de Pesquisas do Cacau em Itabuna, Brasil. Ilhéus, CEPLAC/CEPEC, 1980. 8p.(Boletim Técnico, 78)

ODUM, E.P. Ecologia. Rio de Janeiro, Guanabara Koogan, 1983. $434 \mathrm{p}$

SALT, G.W. A comment on the use of the term "emergent properties". Am. Nat., 113:145-148, 1979.

SILVA, L.F. Alterações edáficas provocadas por essências florestais implantadas em solos de tabuleiro no Sul da Bahia. R. Theobroma, 18:259-267, 1988.
SILVA, L.F. Classes de solos de tabuleiro do sudeste da Bahia. Agrotrópica, 3:101-108, 1991.

SILVA, L.F. \& MENDONCA, J.R. Terras avistadas por Cabral (Mata Atlântica) 500 anos de Devastação. Ilhéus, Universidade Estadual da Santa Cruz, 2000. 43p.

SILVA, L.F. \& VINHA, S.G. Influência da matéria orgânica no comportamento de espécies florestais, em plantio puro e misto, em solos de tabuleiro do sudeste baiano. Agrotrópica, 3:93-99, 1991.

TEDESCO, M.J.; VOLKWEISS, S.J. \& BOHNEN, H. Análises de solo, plantas e outros materiais. Porto Alegre, Universidade Federal do Rio Grande do Sul, 1985. 50p. (Boletim Técnico, 5)

TEIXEIRA, J.L. Conteúdo de nutrientes e produção de eucalipto em diferentes ambientes do Rio Doce-MG. Viçosa, MG, Universidade Federal de Viçosa, 1987. 70p. (Tese de Mestrado)

van der LINDEN, B.A.; MEIJER, M. \& SIPS, P.A. Inventário florestal: Comparação entre a mata primária e secundária no trópico úmido, Bahia, Brasil. Wageningen, Agricultural University Wageningen. Department of Silviculture and Forest Ecology, 1988. 34p.

VELOSO, H.P.; RANGEL FILHO, A.L.R. \& LIMA, J.C.A. Classificação da vegetação brasileira adaptada a um sistema universal. Rio de Janeiro, IBGE, 1991. 124p.

VINHA, S.G. \& LOBÃO, D.E.V.P. Estação ecológica do PauBrasil, Porto Seguro, Bahia. Ilhéus, CEPLAC/CEPEC, 1989. 40 p.

VINHA, S.G. \& PEREIRA, R.C. Produção de folhedo e sua sazonalidade em 10 espécies arbóreas nativas no Sul da Bahia. R. Theobroma, 13:327-341, 1983.

VINHA, S.G.; CARVALHO, A.M. \& SILVA, L.A.M. Taxa de decomposição do folhedo de dez espécies de árvores nativas no Sul da Bahia, Brasil. R. Theobroma, 15:207-212, 1985.

YOST, R.; CALDWELL, R.; CONSTANTINIDES, M.; HERBERT, D. \& FOWNES, J. The sustainability of agriculture and forestry production systems on soils with low pH. In: MONIZ, A.C.; FURLANI, A.M.C.; SCHAEFFERT, R.E.; FAGERIA, N.K.; ROSOLEM, C.A. \& CANTARELLA, H., eds. Plant soil interactions at low $\mathrm{pH}$ : sustainable agriculture and forestry production. Campinas/Viçosa, MG, Brazilian Soil Science Society, 1997. p.29-38. 